\title{
DANA INVESTASI REAL ESTAT SYARIAH SEBAGAI SARANA INVESTASI WAKAF UANG
}

\author{
Edy Setyawan, Eef Saefulloh dan Anis Haerunisa \\ Fakultas Syariah dan Ekonomi Islam \\ Institut Agama Islam Negeri Syekh Nurjati Cirebon \\ email: edysetyawano@yahoo.com, eefsae2003@gmail.com dan haerunisa17@gmail.com
}

\begin{abstract}
Cash waqf still raises the debate in terms of its management, because its utilization is feared will not last longer. To make the cash waqf eternal, it is necessary to discover a new longterm management manner, one of which is investment. Islamic Real Estate Investment Trust Syariah has high potential on achieve maximum investment returns. The main issues that will be discussed in this paper is regarding the potential application of wakaf investment through Islamic Real Estate Investment Trust Syariah in Indonesia according to positive law. The author using qualitative method and descriptive method in analyzing the issues. The data collected through in-depth interviews, observation, and documentation. Islamic Real Estate Investment Trust Syariah as an investment for cash waqf has been legalized both according to positive law and Syariah, the high economic value still accompanied by high risk threat. But, waqf Investment can be done through balancing the real asset value and manage it in productive way with combining direct investment and indirect investment.
\end{abstract}

Keywords: Islamic Real Estate Investment Trust Syariah, Direct Investment and Indirect Investment.

\begin{abstract}
Abstrak
Wakaf uang masih menimbulkan perdebatan dalam hal pengelolaanya, hal ini karena penggunaanya yang dikhawatirkan tidak akan abadi. Untuk menjadikan wakaf uang abadi dan dapat dimanfaatkan terus menerus, maka perlu adanya upaya pengelolaan yang bersifat jangka panjang, yaitu, investasi. Dana Investasi Real Estat Syariah memiliki potensi untuk memberika hasil yang maksimal terhadap invetasi wakaf uang. Tulisan ini membahas tentang potensi Dana Investasi Real Estat Syariah sebagai sarana investasi wakaf uang di Indonesia berdasarkan hukum positif. Metode yang digunakan dalam penelitian ini adalah metode kualitatif. Adapun data yang dikumpulkan adalah melalui wawancara, observasi, dan dokumentasi. Dana Investasi Real Estat Syariah sebagai sarana investasi wakaf uang sudah legal baik menurut hukum positif maupun menurut Syariah, nilai ekonomisnya yang tinggi masih diiringi ancaman risiko yang tinggi. Namun, Investasi wakaf bisa dilakukan dengan menyeimbangkan kekayaan aset wakaf dan mengelolanya secara produktif dengan menggabungkan investasi langsung dan tidak langsung.
\end{abstract}

Kata Kunci: Dana Investasi Real Estat Syariah, Investasi Langsung dan Investasi Tidak Langsung. 


\section{PENDAHULUAN}

Selama ini paradigma masyarakat secara umum berpandangan bahwa wakaf haruslah berupa tanah, bangunan, perkebunan dan/atau benda tidak bergerak lainnya. Hal ini berkaitan dengan fiqih wakaf yang menerangkan bahwa, aset yang dapat diwakafkan adalah aset yang berwujud, tahan lama, bersifat kekal, dan dapat dimanfaatkan terus menerus. Kini, mulai dikembangkan wakaf dalam bentuk lain, salah satunya, wakaf uang (cash waqf). Uang memang berwujud, tetapi ia bersifat konsumtif yang otomatis tidak bersifat kekal. Uang sebagai sarana berwakaf masih menimbulkan keraguan dalam pengelolaanya karena penggunaanya yang dikhawatirkan tidak akan abadi. Di sisi lain wakaf uang dapat dimanfaatkan secara fleksibel bagi pengembangan usaha produktif dan komersil yang hasilnya dapat dimanfaatkan bagi kepentingan umat.

Melihat potensi wakaf uang yang begitu besar, maka wakaf uang hendaknya diberi ruang untuk membumi di Indonesia. Hal ini direspon baik oleh pemerintah dengan disahkannya Undang-undang Nomor 41 Tahun 2004 Tentang Wakaf, dimana Undang-undang ini adalah payung hukum bagi wakaf uang di Indonesia. Untuk menjadikan wakaf uang abadi dan dapat dimanfaatkan secara terus menerus, maka perlu adanya upaya pengelolaan yang bersifat jangka panjang, yaitu, investasi. Investasi wakaf uang menjadi hal penting mengingat tujuan wakaf yang harus bermanfaat sebesar-besarnya dan selamalamanya. Salah satu bentuk investasi yang bisa dilakukan adalah pada Dana Investasi Real Estat (DIRE) Syariah, suatu instrumen investasi baru di Indonesia. Peraturan menyangkut DIRE Syariah ini sudah ada dan berlaku di Indonesia. Yaitu Peraturan Otoritas Jasa Keuangan Nomor 30/ POJK.04/2016. Tulisan ini kemudian membahas tinjauan hukum pengelolaan wakaf uang dalam bentuk DIRE Syariah di Indonesia.
Dalam mengkaji hal diatas, penulis memiliki tiga rumusan masalah, yaitu pertama, bagaimana manajemen investasi wakaf uang menurut hukum positif di Indonesia? Kedua, bagaimana potensi penerapan investasi wakaf uang melalui Dana Investasi Real Estat (DIRE) Syariah di Indonesia? Dan ketiga, bagaimana pola investasi wakaf uang yang dapat dilakukan guna memproduktifkan wakaf di Indonesia?

\section{LITERATURE REVIEW}

Penelitian tentang Dana Investasi Real Estat Syariah sebagai sarana investasi wakaf uang mungkin sudah banyak dilakukan. Berikut penelitian terdahulu sebagai berikut, pertama, Dian Masyita, et al., dalam $A$ Dynamic Model for Cash Waqf as One of The Alternative Instrument for Poverty Allevation in Indonesia dengan melakukan penelitian di Indonesia pada tahun 2005, meneliti model investasi portofolio yang dinamis sebagai salah satu instrumen alternatif pengelolaan wakaf. Dian menawarkan sertifikat wakaf tunai untuk memanfaatkan dana tersebut di berbagai portofolio investasi. Dan pengembalian dana kelolaan yang akan diberikan untuk tujuan tertentu misalnya pengembangan fasilitas umum, rehabilitasi orang miskin, dan sebagainya. ${ }^{1}$

Kedua, Latifah K. Wardhani dalam Pengelolaan Wakaf Uang dalam Bentuk Reksa Dana Syariah (Suatu Tinjauan Hukum Pengeloaan Wakaf Uang dalam Bentuk Reksa Dana Syariah di Badan Wakaf Indonesia) pada tahun 2011 meneliti di Badan Wakaf Indonesia. Menurut Lathifah BWI telah memenuhi persyaratan untuk mengelola wakaf uang dalam bentuk

${ }^{1}$ Dian Masyita, et al., "A Dynamic Model for Cash Waqf Management As One Of the Alternative Instrument for the Poverty Allevation In Indonesia." disampaikan pada The 23rd International Conference of The System Dynamics Society Massachussets Institute of Technology (MIT), Boston, USA, July 17-21, 2005. Diunduh dari: https://www.researchgate.net/.../Dian_Masyita/...Dyn amic_M. Diakses pPada 21 November 2017. 
investasi khususnya Reksa Dana Syariah, baik dari segi modal dalam bentuk peraturan, dana, maupun sumberdaya manusia (SDM). Namun, hingga kini BWI belum menerapkan pengelolaan wakaf uang karena masih terfokus pada pembinaan Nazhir di Indonesia. Dalam penelitian ini belum sepenuhnya di kemukakan apakah ada alasan lain mengapa BWI belum melakukan investasi wakaf uang di pasar modal. $^{2}$

Dan ketiga, Diana Lestari, dalam Peranan Reksa Dana Syariah dalam Pengelolaan Wakaf Uang pada 2004 melakukan penelitian di Indonesia memaparkan bahwa pada dasarnya peraturan dalam bidang pasar modal telah cukup mengakomodir bagi perlindungan dana wakaf uang yang di investasikan melalui reksa dana syariah, namun pedoman dalam bentuk perundang-undangan khusus untuk pengelolaan wakaf sangat diperlukan. Oleh karena itu dengan adanya pedoman tersebut diharapakan pengelolaan dan pengembangan wakaf uang dapat berlangsung dengan profesional dan akhirnya tujuan dari wakaf pun dapat tercapai. Dalam penelitian ini tidak membahas peraturan BWI yang telah membahas dan mengatur investasi wakaf uang. ${ }^{3}$

Hasil-hasil studi tersebut di atas memiliki kesamaan esensi wilayah kajian dengan penelitian ini. Namun, penelitian mendetail mengenai investasi wakaf uang melalui dana investasi real estat (DIRE) syariah sebagai upaya pengelolaan wakaf produktif di indonesia belum dapat ditemukan. Oleh karenanya, penelitian ini akan membahas investasi DIRE syariah

${ }^{2}$ Latifah K. Wardhani, "Pengelolaan Wakaf Uang dalam Bentuk Reksa Dana Syariah (Suatu Tinjauan Hukum Pengeloaan Wakaf Uang dalam Bentuk Reksa Dana Syariah di Badan Wakaf Indonesia)", Skripsi (Jakarta: Universitas Indonesia, 2011), 138.

${ }^{3}$ Diana Lestari, "Peran Reksa Dana Syariah dalam Pengelolaan Wakaf Uang", Skripsi (Jakarta: Universitas Indonesia, 2004), 31. sebagai instrumen pengembangan wakaf di Indonesia.

\section{METODOLOGI PENELITIAN}

Penelitian ini berbentuk yuridis normatif, yaitu penelitian atas hukum yang dikonsepsikan dan dikembangkan atas dasar doktrin yang dianut dan dikembangkan dalam kajian-kajian hukum. ${ }^{4}$ Adapun bahan hukum penulis adalah, pertama, Bahan Hukum Primer. Bahan hukum primer yang digunakan adalah UUD 1945, Undangundang Nomor 41 tahun 2004 tentang wakaf, Undang-undang Nomor 8 tahun 1995 tentang pasar modal, Peraturan Pemerintah Nomor 42 tahun 2006, Peraturan Menteri Agama Nomor 4 tahun 2009 tentang Administrasi Pendaftaran Wakaf Uang. Kedua, Bahan Hukum Sekunder. Bahan Hukum Sekunder yang digunakan oleh penulis adalah Peraturan BWI No. 2 tahun 2009, Peraturan BWI No. 1 Tahun 2010, Peraturan BWI No. 2 tahun 2010, Peraturan BWI No. 4 tahun 2010, Fatwa DSN MUI No. 20 tahun 2001, DSN MUI No. 20 tahun 2000, Kompilasi Hukum Islam Buku III, buku hukum, jurnal hukum, skripsi, disertasi, dan artikel hukum. Ketiga, Bahan Hukum Tertier. Bahan Hukum tertier yang penulis gunakan diantaranya Ensiklopedia Hukum, Ensiklopedia Islam, dan Kamus Besar Bahasa Indonesia.

Dalam penelitian ini subyek yang diambil adalah Badan Wakaf Indonesia. Obyek penelitian ini adalah tinjauan hukum DIRE Syariah. Dalam penelitian ini peneliti mengambil lokasi di Badan Wakaf Indonesia Pusat, di Jakarta, Kementerian Agama Republik Indonesia, di Jakarta dan Otoritas Jasa Keuangan, di Jakarta.

Dalam penelitian ini, yang menjadi sumber data primer adalah hasil wawancara mendalam (indepth interview) dengan pihak-pihak yang kompeten di bidang investasi dana wakaf uang. Data sekunder

${ }^{4}$ M. Syamsudin, Operasionalisasi Penelitian Hukum (Jakarta: PT. Raja Grafindo Persada, 2007), 25. 
yang digunakan peneliti adalah kajian pustaka dari literatur-literatur yang mendukung penelitian ini. Adapun jenis penelitian ini adalah penelitian deskriptif. Menurut Whitney dalam Moh. Nazir ${ }^{5}$ bahwa metode deskriptif adalah pencarian fakta dengan interpretasi yang tepat. Dalam penelitian ini penulis akan memberikan gambaran mengenai implementasi investasi wakaf uang melalui Dana Investasi Real Estat (DIRE) Syariah. Metode pengumpulan yang digunakan oleh peneliti adalah: Wawancara mendalam (indepth interview), Observasi, dan Dokumentasi. Dalam mengolah data, penulis menggunakan metode analisis kualitatif. Menurut Keirl dan Miller dalam Moleong yang dimaksud dengan penelitian kualitatif adalah tradisi tertentu dalam ilmu pengetahuan sosial yang secara fundamental bergantung pada pengamatan pada manusia pada kawasannya sendiri, dan berhubungan dengan orangorang tersebut dalam bahasanya dan peristilahannya. $^{6}$

\section{KONSEP DASAR}

\section{Pengertian Wakaf}

Wakaf merupakan bentuk pendistribusian kekayaan masyarkat. Wakaf adalah ibadah ijtima'iyah (ibadah sosial) yang bercorak sosial ekonomi di dalam Islam. Karena manfaat wakaf diambil bagi kepentingan umat, maka aset wakaf harus bersifat kekal. Secara Etimologis wakaf berasal dari kata waqafa-yaqifu-waqfan, yang artinya menghentikan atau menahan (al-habs).

Secara terminologis ulama telah memberikan definisi wakaf. Menurut Mazhab Syafi'i, yang dikemukakan oleh Imam Nawawi, wakaf adalah "menahan harta yang dapat diambil manfaatnya tetapi bukan untuk dirinya, sementara benda itu

\footnotetext{
${ }^{5}$ Lexy J. Moelong, Metode Penelitian Kulitatif (Bandung :Remaja Rosdakarya, 1991), 247.

${ }^{6}$ Lexy J. Moelong, Metode Penelitian Kulitatif, 247.

${ }^{7}$ Mohd. Idris Ramulyo, Hukum Perkawinan, Hukum Kewarisan, Hukum Acara Peradilan Agama dan Zakat (Jakarta: Sinar Grafika, 1995), 132.
}

tetap ada padanya dan digunakan manfaatnya untuk kebaikan dan mendekatkan diri kepada Allah. ${ }^{8}$

Para ulama telah sepakat bahwa tanpa memenuhi rukun dan syarat wakaf, perbuatan wakaf tidak akan terwujud. Jumhur ulama selain Abu Hanifah menyatakan, rukun wakaf terdiri dari waqif, mauquf bih, mauquf alaih, dan shigat. Adapun menurut Imam Abu Hanifah apabila shigat telah diucapkan suatu perbuatan wakaf telah sah secara hukum. Karena beliau berpendapat unsur rukun hanya berupa pengucapan shigat. ${ }^{9}$

Wakaf terbagi menjadi beberapa macam berdasarkan tujuan, batasan waktunya, dan penggunaan barangnya. Macam-macam wakaf berdasarkan tujuannya ada tiga: 1). Wakaf sosial untuk kebaikan masyarakat (waqaf khairi); yaitu apabila tujuan wakafnya untuk kepentingan umum. 2). Wakaf keluarga (waqaf dzurri); yaitu apabila tujuan wakaf untuk memberi manfaat kepada wakif, keluarganya, keturunannya, dan orang-orang tertentu tanpa melihat apakah kaya atau miskin, sakit atau sehat, dan tua atau muda. 3). Wakaf gabungan (waqaf musytarak); yaitu apabila tujuan wakafnya untuk umum dan keluargan bersamaan. ${ }^{10}$

Sedangkan berdasarkan batasan waktunya, wakaf terbagi menjadi dua macam: 1). Wakaf abadi (Wakaf muabbad); yaitu apabila wakafnya berupa barangbarang yang bersifat abadi, seperti tanah, bangunan dengan tanahnya, atau barang bergerak yang ditentukan oleh wakif sebagai wakaf abadi dan produktif, dimana sebagian hasilnya disalurkan sesuai tujuan wakaf,

${ }^{8}$ Elsi Kartika Sari, Pengantar Zakat dan Wakaf (Jakarta: Grasindo, 2006), 55.

${ }^{9}$ Nurul Huda dan Mohamad Heykal, Lembaga Keuangan Islam: Tinjauan Teoritis Dan Praktis (Jakarta: Kencana Prenada Media Group, 2010), 312.

${ }^{10}$ Ibrahim al-Bayumi Ghanim, al-Auqaf wa Siyasah Fi Misra (Mesir: Darul-Asyrku, tt.), 55. Sebagaimana dikutip Muhammad Aziz, "Peran Badan Wakaf Indonesia (BWI) Dalam Mengembangkan Prospek Wakaf Uang di Indonesia," Al-Awqaf , Vol. 8, No. 2 (Desember, 2015): 150 . 
sedangkan sisanya untuk biaya perwatan wakaf dan mengganti kerusakannya. 2). Wakaf sementara (waqaf muaqqat); yaitu apabila barang yang diwakafkan berupa barang-barang mudah rusak ketika dipergunakan tanpa memberi syarat untuk mengganti bagian yang rusak. Wakaf sementara juga bisa dikarenakan oleh keinginan wakif yang memberi batasan waktu ketika mewakafkan barangnya. ${ }^{11}$

\section{Wakaf Uang di dalam Hukum Islam}

Wakaf uang adalah wakaf berupa uang tunai yang diinvestasikan ke dalam sektor-sektor ekonomi yang menguntungkan dengan ketentuan prosentase tertentu digunakan untuk pelayanan sosial. $^{12}$ Secara lebih khusus pengertian wakaf uang dalam konteks regulasi di Indonesia adalah wakaf berupa harta benda bergerak uang, dengan mata uang rupiah melalui lembaga keuangan syariah yang ditunjuk pemerintah yang mengeluarkan sertifikat Wakaf Uang.

Secara historis, wakaf uang telah ada pada abad $16 \mathrm{M}$, pada masa kekuasaan Turki Usmani. Pada masa ini asset atau uang tunai yang berasal dari wakaf dikumpulkan dalam pooling fund kemudian oleh nazhir yang ditunjuk oleh pemerintah disalurkan ke sektor bisnis dalam bentuk pinjaman dimana biasanya setelah satu tahun si peminjam tersebut mengembalikan pinjaman pokok plus extra return. Kemudian extra return yang telah diperoleh dan telah terakumulasi digunakan untuk membiayai kebutuhan

${ }^{11}$ Ibrahim al-Bayumi Ghanim, al-Auqaf wa Siyasah Fi Misra (Mesir: Darul-Asyrku, t.th), 55. Sebagaimana dikutip Muhammad Aziz, "Peran Badan Wakaf Indonesia (BWI) Dalam Mengembangkan Prospek Wakaf Uang di Indonesia", Al-Awqaf, Vol. 8, No. 2 (2015): 150.

${ }^{12} \mathrm{Abu}$ Bakar dan Chaider S. Bamualim, Filantropi Islam da Keadilan Sosial (Jakarta: CSRC UIN Jakarta, 2006), 78.

${ }^{13}$ Peraturan Pemerintah No. 42 Tahun 2006 Tentang Pelaksanaan Undang-undang No. 41 Tahun 2004 tentang Wakaf, Pasal 22. sosial, tempat ibadah, pendidikan, atau lahan perkuburan. ${ }^{14}$

Karenanya Undang-undang No. 41 Tahun 2004 dan fatwa MUI tentang diperbolehkannya wakaf dengan uang, merupakan hal baru bagi umat Islam Indonesia. MUI sendiri dalam fatwanya yang membolehkan wakaf uang selain menggunakan dasar hukum Al-Quran dan Hadits yang berkaitan dengan wakaf, juga secara khusus memperhatikan pandangan para ulama yang telah membolehkan wakaf dengan uang. Beberapa pandangan yang digunakan MUI tersebut antara lain adalah, Pendapat Imam Az-Zuhri bahwa mewakafkan dinar hukumnya boleh, dengan cara menjadikan dinar tersebut sebagai modal usaha kemudian keuntungannya disalurkan pada mauquf alaih. Pandangan dari ulama Mazhab Hanafi yang membolehkan wakaf uang dinar dan dirham sebagai pengecualian, atas dasar Istihsan bi al-'Urf (hukum yang ditetapkan berdasarkan adat kebiasaan), berdasarkan hadits yang diriwayatkan Abdullah bin Mas'ud r.a: "Apa yang dipandang baik oleh kaum muslimin maka dalam pandangan Allah SWT adalah baik, dan apa yang dipandang buruk oleh kaum muslimin maka dalam pandangan Allah SWT pun buruk". Pendapat sebagian ulama Mazhab Syafi'i: "Abu Tsaur meriwayatkan dari Imam Syafi'i tentang kebolehan wakaf dinar dan dirham". Walaupun banyak dari kalangan ulama yang telah membolehkan wakaf uang, namun ada pula sebagian ulama yang sulit menerima pendapat bahwa sah hukumnya mewakafkan dinar dan dirham. ${ }^{15}$

Adapun alasan para ulama yang tidak membolehkan berwakaf dengan uang, diantaranya, Bahwa uang bisa habis zatnya sekali pakai. Uang hanya bisa dimanfaatkan dengan membelanjakan sehingga bendanya

\footnotetext{
${ }^{14}$ Farid Wadjdy dan Mursydi, Wakaf dan Kesejahteraan Umat: Filantropi Islam yang Hampir Dilupakan (Yogyakarta: Pustaka Pelajar, 2007), 78.

15 Komisi Fatwa Majelis Ulama Indonesia, Fatwa tentang Wakaf Uang, pada tanggal 11 Mei 2002.
} 
bisa lenyap, sedangkan inti ajaran wakaf adalah pada kesinambungan hasil dari modal dasar yang tetap lazim kekal. Oleh karena itu, ada persyaratan agar benda yang akan diwakafkan itu adalah benda yang tahan lama, tidak habis dipakai. Uang seperti dinar dan dirham diciptakan sebagai alat tukar yang mudah, orang melakukan transaksi jual beli, bukan untuk ditarik manfaatnya dengan mempersewakan zatnya. 16

Dalam Al-Is'af fi Ahkami al-Awqaf, al-Tharablis menyatakan sebagian ulama klasik merasa aneh ketika mendengar fatwa yang dikeluarkan oleh Muhammad bin Abdullah al-Anshori, murid dari Zufar, sahabat Abu Hanifah, tentang bolehnya berwakaf dalam bentuk uang kontan dinar dan dirham, dan dalam bentuk komoditas yang dapat ditimbang atau ditukar, seperti makanan gandum. Hal ini membuat mereka merasa aneh karena tidak mungkin mempersewakan benda-benda seperti itu, oleh karena itu mereka segera mempersoalkannya dengan mempertanyakan apa yang kita dapat lakukan dengan dana tunai dirham? Atas pertanyaan ini Muhammad bin Abdullah alAnshori menjelaskan dengan mengatakan: "kita investasikan dana itu dengan cara mudharabah dan labanya kita sedekahkan. Kita jual benda makanan itu, harganya kita putar dengan usaha mudharabah hasilnya disedekahkan." 17

Wahbah Zuhaili menjelaskan secara tegas bahwa ulama Mazhab Maliki memperbolehkan wakaf uang, mengingat manfaat uang masih dalam cakupan hadis Nabi Muhammad SAW dan benda sejenis yang diwakafkan oleh para sahabat, seperti baju perang, binatang dan harta lainnya serta

\footnotetext{
${ }^{16}$ Mustafa Edwin Nasution dan Uswatun Hasanah, ed., Wakaf Tunai Inovasi Finansial Islam: Peluang dan Tantangan dalam Mewujudkan Kesejahteraan Umat (Depok: PSTTI-UI, 2006), 98.

${ }^{17}$ Mustafa Edwin Nasution dan Uswatun Hasanah, ed., Wakaf Tunai Inovasi Finansial Islam: Peluang dan Tantangan dalam Mewujudkan Kesejahteraan Umat (Depok: PSTTI-UI, 2006), 99.
}

hal tersebut mendapatkan pengakuan dari Rasulullah SAW. Secara qiyas, wakaf uang dianalogikan dengan baju perang dan binatang. Qiyas ini telah memenuhi syarat 'illah (sebab persamaan), dan jami' (titik persamaan) terdapat dalam qiyas dan yang diqiyaskan. Sama-sama benda bergerak dan tidak kekal, yang akan mengancam eksistensi dan kesinambungan aset wakaf. ${ }^{18}$

Walaupun ada perbedaan pendapat dikalangan para ulama mengenai sah tidaknya wakaf uang, namun mengingat manfaat wakaf uang yang begitu besar bila dikembangkan dengan baik bagi kemaslahatan umat, pengelolaan wakaf uang tetap menjadi pilihan yang menarik bagi umat Islam untuk dikembangkan.

\section{Investasi Wakaf Uang}

Investasi wakaf uang adalah investasi atau penyertaan modal dari dana wakaf yang terkumpul untuk proyek-proyek produktif bagi kemaslahatan umat melalui investasi secara langsung dan tidak langsung. ${ }^{19}$ Pemanfaatan dan investasi wakaf uang adalah manajemen pengelolaan wakaf uang pasca kegiatan fundraising agar dapat berfungsi dan bermanfaat bagi kebutuhan masyarakat baik secara langsung maupun tidak lansung. Pemanfaatan dana pokok wakaf uang secara langsung bisa disalurkan kepada masyarakat yang membutuhkan dengan akad pinjaman tanpa bunga dengan djkembalikan Iagi secara utuh dana pokoknya. sedangkan pemanfaatan dana wakaf uang secara tidak langsung dilakukan kegiatan investasi terlebih dahulu kemudian hasil keuntungan investasinya disalurkan kepada masyarakat. Sebagai mana al-Hasan telah membagi pemanfaatan wakaf uang

18 Departemen Agama RI, Pedoman Pengelolaan dan Pengembangan Wakaf (Jakarta: Direktorat Pemberdayaan Wakaf dan Direkterot Jenderal Bimbingan Masyarakat Islam Depag RI, 2006), 212.

${ }^{19}$ Mifathul Huda Almantiq, "Model dan Mekanisme Pengeolaan Wakaf Uang di Indonesia," Al-Awqaf, Vol. 10, No. 1 (2017): 31. 
menjadi dua metode yaitu metode Qardl al Hasan dan metode Ististmaar (investasi). ${ }^{20}$

Dalam pengelolaan dan pengembangan atas harta benda wakaf uang hanya dapat dilakukan melalui investasi pada produk-produk LKS dan/atau instrumen keuangan syariah. Berbagai alternatif investasi yang dapat dilakukan oleh LKS diantaranya: investasi Mudarabah, investasi Musyarakah, investasi Ijarah, dan investasi Murabahah. Senada dengan pendapat itu Siregar, menjelaskan bahwa dana wakaf harus disetorkan oleh wakif atau Nazhir melalui LKS-PWU sebagai pemanfaatan dan investasi dengan beberapa produk perbankan syariah, yaitu Giro Wadiah, Tabungan Wadiah, Tabungan Mudarabah, Deposito Mudarabah dan Mudrabah Mukayyadah. ${ }^{21}$

Produk-produk ini ada yang bersifat simpanan dana saja (Giro wadiah dan Tabungan Wadiah) ada pula yang bersifat investasi tidak langsung (Tabungan Mudarabah, Deposito Mudarabah) maupun investasi langsung (Mudarabah mukayyadah). Namun proses ini akan lancar dan terus meningkat jika terjadi kerja sama antara kementrian agama, BWI, Nazhir dan LKS-PWU dalam sebuah program penggalangan dana (fundraising) wakaf uang. 22

Islam menganjurkan agar menggunakan harta secara efektif dan efisien dan mendorong agar setiap kekayaan yang ada pada kita, diinvestasikan di sektor riil. Islam tidak menyukai adanya penimbunan harta yang sia-sia dan membiarkan aset yang menganggur. Hal ini sesuai dengan penjelasan Imam Al-Ghazali

\footnotetext{
${ }^{20}$ Mifathul Huda Almantiq, "Model dan Mekanisme Pengeolaan Wakaf Uang Di Indonesia", Al-Awqaf, Vol. 10, No. 1 (2017): 31.

${ }^{21}$ Mifathul Huda Almantiq, "Model dan Mekanisme Pengeolaan Wakaf Uang Di Indonesia", Al-Awqaf, Vol. 10, No. 1 (2017): 31.

${ }^{22}$ Mifathul Huda Almantiq, "Model dan Mekanisme Pengeolaan Wakaf Uang Di Indonesia", Al-Awqaf, Vol. 10, No. 1 (2017): 31.
}

bahwa penimbunan uang (al-iktinaz) merupakan perbuatan zalim dan dapat menghilangkan hikmah yang dalamnya. ${ }^{23}$

Investasi wakaf uang ini kemudian menjadi perhatian BWI. Hal terbukti dengan dikeluarakannya Peraturan BWI Nomor 1 Tahun 2009 tentang Pedoman Pengelolaan dan Pengembangan Harta Benda Wakaf Bergerak Berupa Uang. Investasi wakaf uang ini secara spesifik diatur dalam BAB V. Pengaturan Investasi wakaf uang lebih jelasnya diterangkan dalam Peraturan Badan Wakaf Indonesia Nomor 4 Tahun 2010 tentang Pedoman Pengelolaan dan Pengembangan Harta Benda Wakaf. Dijelaskan dalam pasal 7 peraturan tersebut bahwa Pengelolaan dan pengembangan wakaf uang hanya dapat dilakukan melalui investasi pada produk-produk LKS dan/atau instrumen keuangan syariah.Dalam hal LKSPWU menerima wakaf uang untuk jangka waktu tertentu, Nazhir hanya dapat melakukan pengelolaan dan pengembangan di LKS-PWU dimaksud.

\section{Dana Investasi Real Estat (DIRE) Syariah}

Dana Investasi Real Estat (DIRE) adalah wadah untuk menghimpun dana masyarakat, yang selanjutnya diinvestasikan pada aset real estat, aset yang berkaitan dengan Real Estat dan atau kas dan setara kas. DIRE berinvestasi pada: Aset Real Estat (tanah secara fisik dan bangunan yang ada di atasnya) paling kurang $50 \%$ dari Nilai Aktiva Bersih (NAB), Aset Real Estat dan Aset yang berkaitan dengan Real Estat di wilayah Indonesia (Efek Perusahaan Real Estat yang tercatat di Bursa Efek dan atau diterbitkan oleh Perusahan Real Estat) paling kurang $80 \%$ dari NAB dengan ketentuan investasi pada Aset Real Estat paling kurang $50 \%$ dari NAB; dan/ atau, kas dan setara kas tidak lebih dari $20 \% \mathrm{NAB}^{24}$

\footnotetext{
${ }^{23}$ Euis Amalia, Sejarah Pemikiran Islam dari Masa Klasik hingga Kontemporer, Cet. Ke-2 (Jakarta: Granada Press, 2007), 128.

${ }^{24}$ Peraturan Otoritas Jasa Keuangan Nomor 19/POJK.04/2016 Tentang Pedoman Bagi Manajer Investasi Dan Bank Kustodian Yang Melakukan Pengelolaan Dana Investasi Real Estat BerbentukKontrak Investasi Kolektif, Pasal 11.
} 
DIRE dilarang berinvestasi pada: tanah kosong; atau properti yang masih dalam tahap pembangunan(tidak termasuk dekorasi ulang, perbaikan (retrofitting) dan renovasi). DIRE dapat melakukan Penawaran Umum atau tidak melakukan Penawaran Umum atas Unit Penyertaannya. DIRE dapat mencatatkan Unit Penyertaannya di Bursa Efek. ${ }^{25}$

Dana Investasi Real Estat (DIRE) Syariah diatur dalam peraturan Otoritas Jasa Keuangan Nomor 30/POJK.04/2016. Dana Investasi Real Estat Syariah adalah wadah investasi yang digunakan untuk mengumpulkan dana dari masyarakat untuk selanjutnya diinvestasikan dalam aset real estat, aset yang berkaitan dengan real estat, dan/atau kas dan setara kas yang tidak bertentangan dengan prinsip syariah di pasar modal. ${ }^{26}$ Menurut peraturan Otoritas Jasa Keuangan Nomor 30/ POJK.04/2016, real estat adalah tanah fisik dan bangunan di atasnya. Aset yang berkaitan dengan real estat adalah Efek Perusahaan real estat yang tercatat di Bursa Efek Indonesia dan/atau dikeluarkan oleh perusahaan real estat. Perusahaan real estat adalah perusahaan yang mengelola real estat sebagai kegiatan usaha utamanya. ${ }^{27}$

Dalam proses penciptaan instrumen keuangan, terdapat perbedaan antara instrumen keuangan sesuai Syariah dan berbasis Syariah. Aznan bin Hasan menggambarkan bahwa perspektif berbasis Syariah adalah "Dimana aset yang digunakan dalam produk keuangan syariah benar-benar ditransaksikan, tidak hanya

\footnotetext{
${ }^{25}$ Peraturan Otoritas Jasa Keuangan Nomor 19/POJK.04/2016 tentang Pedoman bagi Manajer Investasi dan Bank Kustodian yang Melakukan Pengelolaan Dana Investasi Real Estat Berbentuk Kontrak Investasi Kolektif, Pasal 5 (a).

${ }^{26}$ Otoritas Jasa Keuangan,Peraturan Otoritas Jasa Keungan Nomor 30/POJK.04/2016 tentang Dana Investasi Real Estat Syariah Berbentuk KIK Pasal 1 Nomor 1.

${ }^{27}$ Otoritas Jasa Keuangan,Peraturan Otoritas Jasa Keungan Nomor 30/POJK.04/2016 tentang Dana Investasi Real Estat Syariah Berbentuk KIK Pasal 1 Nomor 4.
}

digunakan sebagai "jalan", sehingga hasil yang di dapat berbeda dengan produk konvensional.", sedangkan perspektif sesuai Syariah adalah dimana "aset yang digunakan dalam produk keuangan syariah dapat dimanfaatkan untuk mencapai tujuan yang sama seperti produk konvensional". Ilustrasi ini berlaku juga untuk instrumen DIRE. $^{28}$

Dalam DIRE yang sesuai syariah, DIRE dianggap memenuhi Prinsip Syariah dalam pasar modal selama tidak bertentangan dengan prinsip-prinsip syariah. Kegiatan/tindakan yang bertentangan dengan prinsip Syariah (sesuai fatwa DSNMUI Nomor: 80/DSN-MUI/III/2011), antara lain:

a. Maisir, yaitu setiap kegiatan yang melibatkan perjudian dimana pihak yang memenangkan perjudian akan mengambil taruhannya.

b. Gharar, yaitu ketidakpastian dalam suatu akad, baik mengenai kualitas atau kuantitas objek akad maupun mengenai penyerahannya.

c. Riba, yaitu tambahan yang diberikan dalam pertukaran barang-barang ribawi (al-amwal al-ribawiyah) dan tambahan yang diberikan atas produk utang dengan imbalan penangguhan pembayaran secara mutlak.

d. Bathil, yaitu Jual beli bathil atau batal adalah jual beli yang tidak sesuai dengan rukun dan akadnya (ketentuan asal/pokok dan sifatnya) atau tidak dibenarkan oleh syariah Islam.

e. Bai' al-ma'dum, yaitu melakukan penjualan atas barang (efek syariah) yang belum dimiliki (short selling).

f. Ikhtikar, yaitu membeli suatu barang yang sangat diperlukan masyarakat pada saat harga mahal dan menimbunnya dengan tujuan untuk

${ }^{28}$ Yoga Prakasa, "Islamic Real Estate Invesment Trust as an Investment Asset for Waqf Management in Indonesia”, Makalah di Presentasikan pada Konferensi Internasioan Ekonomi Islam Gajah Mada yang ke-1, Yogyakarta, 2016, 15. 
menjualnya kembali pada saat harganya lebih mahal.

g. Taghir, yaitu upaya mempengaruhi orang lain, baik dengan ucapan maupun tindakan yang mengandung kebohongan, agar terdorong untuk melakukan transaksi.

h. Ghabn, yaitu ketiadkseimbangan antara dua barang (objek) yang dipertukarkan dalam suatu akad, baik segi kualitas maupun kuantitas.

i. Talaqqi al-rukban, yaitu bagian dari ghabn atau jual beli atas barang dengan harga jauh di bawah harga pasar karena pihak penjual tidak mengetahui harga tersebut.

j. Tadlis, yaitu tindakan menyembunyikan kecacatan objek akad yang seolah-olah objek akad tersebut tidak cacat.

k. Ghisysy, yaitu satu bentuk tadlis atau penjual menjelaskan/memaparkan keunggulan barang yang dijual serta menyembunyikan kecacatannya.

1. Tanjusy/Najsy yaitu, tindakan menawar barang dengan harga lebih tinggi oleh pihak yang tidak bermaksud membelinya, untuk menimbulkan kesan banyak pihak yang berminat membelinya.

m. Dharar yaitu, tindakan yang dapat menimbulkan bahaya atau kerugian bagi pihak lain.

n. Risywah artinya, suatu pemberian yang bertujuan untuk mengambil sesuatu yang bukan haknya, membenarkan yang bathil dan menjadikan yang bathil sebagai sesuatu yang benar.

o. Maksiat dan Zalim, yaitu perbuatan yang merugikan, mengambil atau menghalangi hak orang lain yang tidak dibenarkan secara syariah, sehingga dapat dianggap sebagai salah satu bentuk penganiayaan. ${ }^{29}$

\footnotetext{
${ }^{29}$ Fatwa DSN-MUI Nomor: 80/DSNMUI/III/2011.
}

Meskipun DIRE tersebut berbentuk konvensional. DIRE konvensional dianggap sesuai Syariah jika tidak ada barang yang dilarang Syariah, tidak ada pinjaman konvensional yang dilakukan oleh DIRE, dan DIRE tidak menjalani transaksi yang dilarang oleh Syariah. Hal Ini bisa dianalogikan dengan saham yang sesuai dengan Syariah.

Saham syariah harus melalui proses screening sehingga dapat dipastikan bahwa saham tersebut sesuai syariah. Proses tersebut adalah proses Business Screening dan Fincial Screening. Business Screeninguntuk memastikan tidak melakukan kegiatan usaha antara lain sebagai berikut: (1) perjudian dan sejenisnya, (2) perdagangan yang dilarang), (3) Jasa keuangan ribawi, (4) Jual beli risiko yang mengandung ketidakpastian (Gharar) dan/atau judi (maisir), (5) produksi atau distribusi barang haram, merusak moral atau mudharat, (6) transaksi suap. Financial Screening meliputi melakukan screening pada total utang berbasis bunga dibanding total aset tidak lebih dari 45\%, dan pendapatan non-halal dibanding total pendapatan tidak lebih dari $10 \% .^{30}$

Dalam DIRE berbasis syariah, DIRE dirancang sebagai instrumen syariah sejak awal, mulai dari konstruksi yang memenuhi Prinsip Syariah di Pasar Modal dan dicatatkan di daftar efek Syariah (DES) sepanjang waktu. Misalnya, hotel DIRE syariah dibuat dengan pengawasan Dewan Pengawas Syariah (DPS) untuk memastikan kepatuhan Syariah dalam hal pengoprasian dan struktur keuangannya. Oleh karenanya manajemen hotel harus memastikan bahwa tidak ada alkohol dan memastikan bahwa tamu non-mahram tidak memasuki hotel DIRE. ini bisa serupa dengan Sukuk. Oleh karena itu, tidak mungkin jika DIRE

${ }^{30}$ Otoritas Jasa Keungan, Mengenal Pasar Modal Syariah (Jakarta: Direktorat Pasar Modal Syariah, 2016), 23. 
berbasis syariah akan disingkirkan dari DES karena didesain dan diawasi oleh DPS. ${ }^{31}$

Di Indonesia, OJK ataupun MUI tidak menetapkan DIRE syariah sebagai DIRE yang sesuai dengan prinsip Syariah atau DIRE yang berbasis Syariah. Di Indonesia, DIRE syariah yang dimaksud adalah keduanya, sehingga ketika dimasa depan terdapat emiten yang menerbitkan DIRE sesuai prinsip Syariah atau berbasis syariah, maka DIRE tersebut disebut sebagai DIRE Syariah. $^{32}$

\section{PEMBAHASAN DAN DISKUSI \\ Manajemen Investasi Wakaf Uang Menurut Hukum Positif di Indonesia}

Di Indonesia, otoritas yang mengatur investasi wakaf uang adalah Badan Wakaf Indonesia (BWI) khususnya Divisi Pengelolaan dan Pengembangan Wakaf. Dalam hal pengelolaan wakaf uang, tugas dari divisi ini adalah Membantu dan membina Nazhir dalam mengelola wakaf uang, dan membantu memudahkan membuat studi kelayakan program wakaf uang. Wakaf uang selama 2017 adalah Rp. 195.861.650.402..$^{33}$

Dinyatakan dalam Peraturan Pemerintah Republik Indonesia Nomor 42 Tahun 2006 pasal 48, bahwa Pengelolaan dan pengembangan harta benda wakaf harus berpedoman pada peraturan BWI. Pengelolaan dan pengembangan atas harta benda wakaf uang hanya dapat dilakukan

${ }^{31}$ Yoga Prakasa, "Islamic Real Estate Invesment Trust as an Investment Asset for Waqf Management in Indonesia”, Makalah di Presentasikan pada Konferensi Internasioan Ekonomi Islam Gajah Mada yang ke-1, Yogyakarta, 2016, 15.

${ }^{32}$ Yoga Prakasa, "Islamic Real Estate Invesment Trust as an Investment Asset for Waqf Management in Indonesia”, Makalah di Presentasikan pada Konferensi Internasioan Ekonomi Islam Gajah Mada yang ke-1, Yogyakarta, 2016, 15.

${ }^{33}$ Wawancara Bersama Sigit Indra Prianto, Staff Divisi Pengelolaan dan Pengembangan Wakaf BWI, Di Kantor Badan Wakaf Indonesia, Gedung Bayt Al-Quran, Pintu Gerbang 1, Taman Mini Indonesia Indah, Jakarta Timur, Jumat, 19 Januari 2018 . melalui investasi pada produk-produk LKS dan/atau Instrumen keuangan Syariah.

Menindak lanjuti amanat PP tersebut, BWI mengeluarkan beberapa peraturan BWI terkait pedoman pengelolaan wakaf uang, khususnya dalam investasi wakaf uang. Peraturan tersebut adalah Peraturan BWI Nomor 1 Tahun 2009 Tentang Pedoman Pengelolaan Dan Pengembangan Harta Benda Wakaf Berupa Uang. Dan Peraturan BWI Nomor 4 Tahun 2010 Tentang Pedoman Pengelolaan Dan Pengembangan Harta Benda Wakaf.

Dalam Peraturan BWI Nomor 1 Tahun 2009 Tentang Pedoman Pengelolaan Dan Pengembangan Harta Benda Wakaf Berupa Uang Bab $\mathrm{V}$ dinyatakan bahwa Investasi Wakaf Uang ditujukan untuk proyek-proyek produktif bagi kemaslahatan umat melalui investasi secara langsung dan tidak langsung. Investasi secara langsung sebagaimana dimaksud pada ayat adalah investasi pada proyek-proyek yang dikelola oleh Nazhir. Investasi secara tidak langsung sebagaimana dimaksud adalah investasi melalui lembaga yang memenuhi kriteria kelayakan kelembagaan dan menguntungkan. Investasi Wakaf Uang dapat dilakukan melalui deposito di Bank Syariah dengan ekspektasi bagi hasil yang paling menguntungkan.

Investasi Wakaf Uang secara langsung pada proyek-proyek yang dikelola oleh Nazhir dapat dilakukan apabila proyek tersebut memenuhi persyaratan: a. usaha proyek dijalankan sesuai dengan syariah Islam; b. tingkat kelayakan proyek memenuhi syarat kelayakan proyek sesuai prinsip 5 C (Character, Condition, Capital, Capacity, Collateral), dan $3 \mathrm{P}$ (People, Purpose, Payment); c. sumber pengembalian dapat dihitung berdasarkan studi kelayakan. ${ }^{34}$

${ }^{34}$ Peraturan tersebut adalah Peraturan BWI Nomor 1 Tahun 2009 Tentang Pedoman Pengelolaan Dan Pengembangan Harta Benda Wakaf Berupa Uang Pasal 11. 
Investasi Wakaf Uang secara langsung sebagaimana dimaksud adalah dilakukan melalui produk dengan akad mudharabah muqayyadah di LKS. Investasi Wakaf Uang secara langsung dijamin oleh Cash Collateral yang dananya diperoleh dari manfaat investasi kas wakaf yang dicadangkan sebesar $100 \%$ (seratus perseratus) dari jumlah dana wakaf yang diinvestasikan, atau investasi tersebut dijamin oleh asuransi. Dalam hal Nazhir menunjuk suatu lembaga atau perorangan sebagai pelaksana proyek untuk memanfaatkan atau menerima dana wakaf sebagai pembiayaan, maka pembiayaan dibayarkan melalui termin sesuai dengan prestasi kerja. $^{35}$

Pada 10 Nazhir dengan jumlah wakaf uang terbesar, 8 Nazhir wakaf uang menginvestasikannya secara langsung dalam sektorl riil, dan 1 Nazhir wakaf lainnya berinvestasi secara tidak langsung melalui LKS dan Instrumen keuangan Syariah, dan 1 Nazhir lainnya berinvestasi secara langsung dan tidak langsung. Nazhir yang menginvestaikan wakaf uangnya di pasar finansial adalah itu adalah Baitul Maal Muamalat selain sudah investasi di deposito, mereka juga sudah memiliki investasi wakaf uang di Reksa dana dan obligasi. Sedangkan Nazhir yang menggabungkan investasi langsung dan tidak langsung adalah Yayasan Wakaf Bangun Nurani Bangsa yang memiliki investasi properti office building 165 dan juga saham PT. Grha 165.

Jika dilihat dari segi modal dan SDM nya dapat dikatakan bahwa Nazhir wakaf uang selain Yayasan Wakaf Bangun Nurani bangsa dan Baitul Maal Muamalat sudah harus memiliki pemikiran ke arah Investasi tidak langsung di pasar finansial. Ketika Nazhir sudah mendapatkan returnnya, maka bisa dimanfaatkan untuk pembiayaan aset lain agar lebih produktif,

${ }^{35}$ Peraturan tersebut adalah Peraturan BWI Nomor 1 Tahun 2009 Tentang Pedoman Pengelolaan Dan Pengembangan Harta Benda Wakaf Berupa Uang Pasal 11. seperti pembangunan tanah wakaf yang tidak dimanfaatkan, membeli hard asset yang produktif, serta untuk perawatan masjid dan mushola, kegiatan sosial, dan di investasikan lagi. Dengan demikian dana wakaf tersebut memiliki manfaat yang multiply dan tidak akan habis. Nilai nominal dan nilai riil aset juga akan terus meningkat.

Pengelolaan dana wakaf juga terkait bagaimana menjadikan aset tersebut lebih besar atau lebih tinggi produktifitasnya. Artinya jika pemanfaatannya ingin multiply, maka pengelolaannya sebagai sumber dana juga perlu inovasi. Tidak hanya sekedar dengan model tradisional tapi perlu berfikir produktivitas sekaligus dengan pertimbangan efisiensi dan efektifitas.

\section{Potensi Penerapan Investasi Wakaf Uang Melalui Dana Investasi Real Estat (DIRE) Syariah di Indonesia}

Mengenai kelengkapan peraturan mengenai DIRE Syariah, OJK sudah mengeluarkan Peraturan OJK (POJK) Nomor 30/POJK.04/2016 tentang DIRE Syariah. Latar belakang pengeluaran peraturan ini adalah untuk melengkapi produk baru industri pasar modal Syariah di Indonesia. Jika produknya sudah ada, maka aturannya pun sudah tersedia. Misalnya, Ciptadana yang mempunyai produk DIRE Konvensiaonal, sudah mulai memiliki wacana untuk mengkonversi produknya ke Syariah. $^{36}$

Keuntungan/keunggulan DIRE Syariah adalah bahwa asetnya real (berwujud/kelihatan) dan returnnya berupa deviden. Bersamaan dengan itu, resiko investasi di DIRE Syariah adalah Return bisa naik, bisa juga turun. Sampai saat ini belum ada MI yang menerbitkan DIRE Syariah, karena terdapat kendala yang menyulitkan menerbitkan DIRE di

\footnotetext{
${ }^{36}$ Wawancara bersama Arif Machfoed, Kepala Divisi Pasar Modal Syariah, Otoritas Jasa Keuangan, Gedung Soemitro Djojohadikusumo, No. 2-4, Jalan Lapangan Banteng Timur, Ps. Baru, Sawah Besar, Kota Jakarta Pusat, Daerah Khusus Ibukota Jakarta, Selasa, 30 Januari 2018.
} 
Indonesia, yaitu lingkungan perpajakan. Di Indonesia, penerbitan DIRE itu pajaknya berganda ada BPHTB $6 \%$ untuk pembelian. Meskipun sudah ada paket kebijakan ekonomi yang mengurangi pajak bagi DIRE, tetapi hal ini tidak dapat dilaksanakan dengan mudah karena, hal ini bukan sesuatu yang harus diatur dan ditentukan oleh pemerintah pusat, harusnya diatur dan ditentukan oleh pemerintah daerah. Banyak perusahaan properti yang menerbitkan DIRE di luar negeri, hal ini karena di luar negeri regulasinya lebih mudah, lingkungan perpajakn relatif lebih bersahabat dengan industri jasa keuangan, misalnya Singapur. ${ }^{37}$

Kemudian, ada langkah yang ditempuh OJK dalam upaya menarik stakeholder penerbit DIRE Syariah, yaitu OJK melakukan sosialisasi mengenai DIRE syariah untuk menyambut peraturan ini. Dan respon dari stakeholder cukup bagus. Salah satu BUMN sudah menunjukan minatnya untuk menerbitkan DIRE Syariah. ${ }^{38}$

DIRE Syariah bisa menjadi sarana investasi wakaf uang, karena nilai tanah relatif naik setiap tahun, return juga akan naik terus. DIRE juga dikelola oleh manajer investasi (MI) yang profesional, tugas MI inilah yang akan memperhatikan propsek ekonomi suatu produk. Selain pola investasi secara klasik (biasa/menanamkan uang), DIRE juga menjadi sarana untuk menjual aset wakaf.

Underlying asset DIRE berbentuk KIK adalah aset yang memiliki recurring income, misalnya gedung perkantoran, rumah sakit, dan pusat perbelanjaan. Data Bank Indonesia menyebutkan pasar properti

${ }^{37}$ Wawancara bersama Arif Machfoed, Kepala Divisi Pasar Modal Syariah, Otoritas Jasa Keuangan, Gedung Soemitro Djojohadikusumo, No. 2-4, Jalan Lapangan Banteng Timur, Ps. Baru, Sawah Besar, Kota Jakarta Pusat, Daerah Khusus Ibukota Jakarta, Selasa, 30 Januari 2018.

${ }^{38}$ Wawancara bersama Arif Machfoed, Kepala Divisi Pasar Modal Syariah, Otoritas Jasa Keuangan, Gedung Soemitro Djojohadikusumo, No. 2-4, Jalan Lapangan Banteng Timur, Ps. Baru, Sawah Besar, Kota Jakarta Pusat, Daerah Khusus Ibukota Jakarta, Selasa, 30 Januari 2018. di Indonesia selalu mengalami pertumbuhan yang seiring dengan tingkat pertumbuhan ekonomi Indonesia dimana pertumbuhan luasan perkantoran dan ritel rata-rata sebesar 4,09\% dari tahun 2010 s.d. 2014. Dan terif sewanya selalu naik rata-rat $10,18 \% .^{39}$

Seperti sudah diketahui bahwa OJK sudah membuat peraturan DIRE syariah, yang artinya OJK sudah memberikan rekomendasi kepada publik termasuk kepada pemegang kepentingan wakaf uang agar menginvestasikan kelebihan dananya pada produk DIRE Syariah. Sistem investasi DIRE Syariah sudah dibuat sedemikian rupa, dimana sistem pelaksanaanya merupakan kombinasi antara Sukuk dan Reksa Dana Syariah. Kedua produk ini sudah memiliki jaminan pengawasan dari Dewan Syariah Nasional dan juga dari OJK. Sehingga masyarakat tidak usah was-was ketika menginvestasikan dana nya pada DIRE Syariah.

Peraturan yang mengatur Reksa dana Syariah adalah POJK Nomor 19/POJK.04/2015 Tentang Penerbitan dan Persyaratan Reksa dana Syariah. Seluruh ketentuan dan mekanisme Reksa dana Syariah sama dengan Reksadan Konvensional. Dalam peraturan ini Reksa dana Syariah menambahkan ketentuan bahwa pengelolaanya tidak bertentangan dengan prinsip Syariah di pasar modal.

Skema Reksa dana Syariah sama dengan DIRE Syariah, yaitu berbentuk Kontrak investasi kolektif (KIK), atau kontrak dengan menggunkan manajer investasi dan Bank Kustodian. Fatwa mengenai Reksa dana Syariah adalah Fatwa DSN Nomor 20/DSN-MUI/IV/2001 Tentang Pedoman Investasi Untuk Reksa dana Syariah. Secara Akad, DIRE Syariah juga memiliki kesamaan yaitu, akad Wakalah bil ujrah terjadi antara Investor

\footnotetext{
${ }^{39}$ Poltak Hotradero, Bahan Paparan Kepala Divisi Manajemen Informasi Dan Pengembangan Emiten Bursa Efek Indonesia, "DIRE/REITS: Gambaran Global Dan Prospek , Indonesia", Bursa Efek Indonesia, 16.
} 
dengan MI. Akad wadiah terjadi antara Investor dengan Bank kustodian.

Dengan demikian, meskipun tidak ada fatwa mengenai DIRE Syariah, namun DIRE Syariah sudah bisa dikatakan aman secara Syariah karena teknis pelaksanaanya telah ada.

\section{Pola Investasi Wakaf Uang yang Dilakukan Guna Memproduktifkan Wakaf di Indonesia}

Di awal operasi produk wakaf uang, pola pengelolaan wakaf uang yang dilakukan oleh beberapa Nazhir adalah sebagai berikut, misalnya Yayasan Dompet Dhuafa Republika adalah langsung memanfaatkan dana wakaf pada sasaran, tidak menginvestasikannya terlebih dahulu sehingga aset pokok wakaf digunakan untuk membiayai operasional program wakaf, bukan profit atau keuntungannya. Seiring waktu berjalan, lembaga itu terus melakukan evaluasi dan inovasi dalam maksimalisasi pengembangan wakaf uang. Di tahun 2004, Dompet Dhuafa telah melakukan strategi baru antara lain mereka bekerja sama dengan Batasa Capital dan BII Syariah. Kerjasama ini telah berhasil meluncurkan "Wakaf Investasi Dompet Dhuafa Batasa Syariah". ${ }^{40}$

Sebuah produk yang diluncurkan untuk mensinergikan investasi dengan charity demi membangun bangsa. Wakaf tersebut akan dialokasikan untuk mendorong kegiatan sektor rill, khususnya yang berdampak pada pertumbuhan dan perkembangan usaha kecil dan menengah. ${ }^{41}$

Secara konseptual, pengelolaan wakaf uang pada Pos Keadilan Peduli Umat (PKPU) sama dengan pola pengelolaan wakaf uang di Yayasan Dompet Dhuafa Republika diawal operasinya, yaitu

\footnotetext{
${ }^{40}$ Dono Satrio, "Perbandingan Model Pengelolaan Wakaf Uang di Bangladesh dan Indonesia", Skripsi (Jakarta: UIN Syarif Hidayatullah, 2015), 57.

${ }^{41}$ Dono Satrio, "Perbandingan Model Pengelolaan Wakaf Uang di Bangladesh dan Indonesia", 57.
}

langsung memanfaatkan dana wakaf pada sasaran dan tidak menginvestasikannya terlebih dahulu sehingga dana yang digunakan untuk membiayai operasional program wakaf adalah aset pokok wakaf bukan keuntungannya. ${ }^{42}$

Untuk memaksimalkan wakaf uang yang produktif, investasi yang ideal adalah jenis investasi yang dipilih berdasarkan pertimbangan kemanfaatan yang lebih besar (Al-Maslahat Al-Ammah), kebutuhan masyarakat setempat (kearifan lokal), dan keuntungan yang berlipat. Setiap daerah memiliki ke 'khasan' masing-masing, sehingga investasi yang dapat dipilih bisa beragam. $^{43}$

Melihat kondisi sosial dan budaya masyarakat Indonesia, sektor jasa merupakan sektor yang bisa dijadikan andalan investasi untuk beberapa waktu kedepan. Hal ini dapat dilihat dari kebutuhan masyarakat yang semakin tinggi dalam semua bidang kehidupan diera digital. Jika wakaf uang di investasikan untuk membiayai sektor riil, akad yang bisa digunakan adalah akad murabahah atau mudharabah. Penyaluran hasil investasi dapat berupa penyaluran langsung atau tidak langsung, melihat situasi kebutuhan masyarkat setempat dimana Nazhir wakaf itu berada. ${ }^{44}$

Keadaan wakaf di Indonesia harus terus bergerak ke arah produktif, Faktanya tanah wakaf di Indonesia sangat luas, namun banyak yang tidak produktif (mangkrak/tidak di kelola/tidak diurus oleh Nazhir), pengelolaan yang bisa diterapkan agar aset tersebut bisa produktif adalah

\footnotetext{
${ }^{42}$ Dono Satrio, "Perbandingan Model Pengelolaan Wakaf Uang di Bangladesh dan Indonesia", 58.

43 Wawancara bersama Atabik Luthfi, Komisioner BWI 2017-2020, Badan Wakaf Indonesia, Email (Pesan Elektronik), Kamis, 25 Januari 2018.

44 Wawancara bersama Atabik Luthfi, Komisioner BWI 2017-2020, Badan Wakaf Indonesia, Email (Pesan Elektronik), Kamis, 25 Januari 2018.
} 
dengan menggandeng pengusaha atau pihak swasta agar tanah tersebut dijadikan alat usaha yang menghasilkan. Hal ini biasanya terjadi karena masalah pembiayaan. Jika suatu aset wakaf tidak diberdayakan karena kekuarangan pembiayaan, maka aset wakaf tersebut bisa dijual dan/atau ditukar (istibdal) dengan aset wakaf lain yang lebih produktif dengan atas persetujuan wakif dan Nazhir. Namun sebelumnya diupayakan menggandeng pihak ketiga yang memiliki modal.

Memang, jika uang tidak diinvestasikan, nilai nominalnya masih terlihat besar dan aman, tetapi akan tergerus inflasi, maka nilai riil nya akan turun. Sedangkan aset itu yang paling penting adalah nilai riil nya. Dalam investasi, nilai nominal bisa naik bisa turun, tetapi yang penting adalah nilai riilnya. Dalam hal wakaf uang diinvestasikan di instrumen keuangan, itu mudah menilainya. Tapi jika aset nya berupa hard asset seperti tanah, atau peternakan itu harus dinilai secara teliti oleh tim penilai yang memiliki lisensi seperti Kantor Jasa Penilaian Publik (KJPP), mereka belajar keilmuannya dan ada metodenya. Tim penilai komersil itu lebih gampang. Ketika Nazhir melakukan penilaian dan nilai real aset nya naik dan tinggi maka ia sudah produktif. Dan dananya harus diputar kembali agar membawa dampak yang baik kepada mauquf alaih. Minimal aset wakaf itu terjaga, syukur jika menghasilkan. ${ }^{45}$

Untuk mengelola wakaf yang lebih produktif, instrumen keuangan bisa dijadikan sarana untuk berinvestasi bisa beragam seperti perbankan, pasar modal, real asset, tergantung portofolio managementnya. yang penting tujuan investasi itu untuk menyeimbangkan keuntungan, ada mitigasi resiko dan ada spektrumnya. $^{46}$

Seandainya Nazhir wakaf uang di Indonesia mampu mengumpulkan,

\footnotetext{
${ }^{45}$ Wawancara bersama Yoga Prakasa, Assistant Vice President, Product Development \& Management, BNI Asset Management, Plaza Senayan, Sabtu, 20 Januari 2018.

${ }^{46}$ Wawancara bersama Yoga Prakasa, Assistant Vice President, Product Development \& Management, BNI Asset Management, Plaza Senayan, Sabtu, 20 Januari 2018.
}

mengelola dan mengembangkan wakaf, mereka bekerja secara professional dan amanah, maka wakaf di Indonesia bisa menjadi lokomotif perekonomian umat, bangsa dan Negara Indonesia. Investasi harta wakaf dalam tatanan Islam merupakan sesuatu yang berbeda dengan investasi di sektor pemerintah (public sector) maupun sektor swasta (private sector). Sektor wakaf ini kadang-kadang disebut sebagai 'sektor ketiga' (third sector). Third sector inilah yang membawa kemaslahatan umat diluar jangkauan pemerintah. Sehingga ketika pemerintah tidak mampu merangkul kesejahteraan sosial-ekonomi, wakaf ia dapat menjadi pemecah masalah terhadap hal tersebut.

Wakaf dalam Islam mirip dengan sebuah perusahaan di mana terdapat modal untuk dikembangkan yang keuntungannya digunakan bagi kepentingan umat dan mauquf alaih. Yang penting juga adalah menjamin keabadian wakaf, hal ini dijamin dengan adanya ketentuan tidak boleh menjual atau mengubah aset itu menjadi barang konsumtif, tetapi harus menjadikannya sebagai aset produktif. Oleh karenanya, wakaf harus selalu berkembang dan bahkan bertambah menjadi wakafwakaf baru.

Pengembangan harta melalui wakaf tidak didasarkan pada target pencapaian keuntungan bagi pemodal saja, tetapi lebih didasarkan pada unsur kebaikan dan kerja sama. Kegiatan investasi dilakukan dalam upaya mengembangkan, mendayagunakan dan memberi nilai tambah ekonomi, serta meningkatkan nilai manfaat sosial atas harta wakaf.

Kegiatan investasi yang ditujukan pada sektor riil harus menguntungkan sesuai target market dan harus ada mitigasi resiko. Kegiatan ini akan dijalankan dengan menggunakan dana wakaf yang dihimpun sesuai program wakaf, serta dapat juga dilakukan penghimpunan dana dengan pola kerjasama investasi yang bersifat komersil dari para investor menggunakan pola 
Mudharabah, Musyarakah, Ijarah, dan pola investasi komersil lainnya sesuai syariah.

Di tingkat masyarakat, persoalan yang paling mendasar adalah kemiskinan, baik dalam arti khsusus, yaitu seperti yang dicerminkan dengan tingkat pendapatan masyarakat, maupun dalam arti luas yang mencakup aspek kesehatan, pendidikan atau pemenuhan hak-hak asasi pada umumnya. Untuk alternatif sumber dana, wakaf yang dikelola oleh sebuah lembaga nasional seperti Badan Wakaf Indonesia misalnya, seharusnya dapat dijadikan sumber dana potensial dalam mengatasi permasalahan sosial seperti kemiskinan dan aspek permasalahan turunnya.

Masalah sosial kemasyarakatan tidak hanya menjadi tanggung jawab Negara, namun menjadi persoalan bersama yang harus diselesaikan dengan bersama-sama pula. Organisasi kemasyarakatan yang berbasis Islam turut juga bertanggung jawab dengan membangun gerakan sosial yang lebih realistis dalam mengatasi permasalahan ini. Akses sumber daya wakaf patut juga diberikan dan dibuka secara luas kepada organisasi-organisasi Islam dan non Islam yang berafiliasi sosial agar masalah kemiskinan yang ada dapat teratasi. Peran Badan Wakaf Indonesia menjadisemakin penting dalam memainkan perannya.

Tahap paling akhir dari investasi wakaf uang adalah penyalurannya. Pola penyaluran menjadi sangat penting karena penyaluran hasil investasi wakaf harus bisa berkelanjutan dan tidak konsumtif. Penyaluran juga tidak boleh salah sasaran dan harus disesuaikan dengan kebutuhan masyarakat lokal. Bukan hal yang berlebihan jika dilakukan studi analisis untuk mengoptimalkan penyaluran hasil investasi.

Jika penyaluran bersifat konsumtif, misalnya pemberian sembako dan santunan, maka akan habis keesokan harinya. Jika penyaluran melalui pemberian sarana dan prasarana kerja, maka hasil penyaluran tersebut akan terus berkesinambungan dan mendorong kemandirian umat. Contohnya, dari pada memberi ikan, lebih baik memberi alat pancing, daripada memberi beras, lebih baik memberi sawah, daripada memberi palawija, lebih baik memberi kebun, daripada memberi daging sapi dan susu, lebih baik memberi peternakan, atau bisa juga memberikan beasiswa terikat, dimana setelah penerima beasiswa lulus ia harus mengabdi dan memberikan sumbangsih kepada masyarakat. Hal ini bukan berarti bahwa penyaluran hasil investasi tidak boleh diserahkan secara tunai tetapi harus dilihat manfaat yang dirasakan masyarakat secara luas.

Penyaluran juga dapat dilakukan dalam rangka pengembangan wakaf itu sendiri, hal ini sesuai dengan pedoman pada peraturan BWI yang menyatakan bahwa penyaluran harus memberikan manfaat pada pembinaan dan pemberdayaan masyarakat. Hasil investasi dapat disalurkan untuk pembiayaan aset wakaf lain, Model pembiayaan proyek wakaf ada 2 macam yaitu, 1) secara tradisonal, yakni pembiayaan wakaf dengan cara menciptakan wakaf baru untuk melengkapi wakaf yang sudah ada, seperti perluasan Masjid. Setiap perluasan terjadi penambahan pada harta wakaf yang lama. 2) secara kontemporer, yakni melalui pinjaman untuk biaya operasional dan biaya pemeliharaan dalam mengembalikan fungsi wakaf yang mendapat izin dari pemerintah. Dengan penyaluran hasil investasi wakaf uang untuk pembiyaan aset wakaf yang sudah ada atau cara tradisonal, maka Nazhir tidak usah melakukan pinjaman dana untuk menjaga dan memproduktifkan aset wakafnya yang lain.

\section{KESIMPULAN}

Berdasarkan pemaparan dan analisis yang telah dikemukakan, penulis memberikan kesimpulan sebagai berikut, Manajemen investasi wakaf uang di Indonesia sudah sesuai dengan aturan yang berlaku. Yaitu investasi secara langsung dan tidak langsung. Investasi langsung adalah 
investasi pada sektor riil dan program Nazhir, sedangkan Investasi tidak langsung adalah investasi pada produk-produk LKS dan/atau instrumen keuangan Syariah lainnya (sektor finansial). Secara legalitas formal dan secara Syariah produk DIRE syariah sangat aman untuk dijadikan sarana investasi wakaf uang. Hal ini berkaitan dengan sudah adanya rekomendasi OJK dan fatwa DSN-MUI yang bersangkutan dengan DIRE Syariah. Ketersediaan dana wakaf uang, didukung denan peraturan yang telah memadai menjadi modal yang cukup bagi Nazhir untuk berinvestasi pada DIRE Syariah. Dengan adanya dukungan pemerintah berupa aturan-aturan yang memadai, maka pola Investasi yang paling baik untuk memproduktifkan aset wakaf adalah menggabungkan pola investasi secara langsung dan tidak langsung. Hal ini berkaitan dengan upaya menyeimbangkan kekayaan aset wakaf yang nilainya harus selalu dijaga, dilindungi dan dikembangkan dengan sebaran investasi yang memberikan keuntungan.

\section{DAFTAR PUSTAKA}

Amalia, Euis. Sejarah Pemikiran Islam dari Masa Klasik hingga Kontemporer, Cet. Ke-2. Jakarta: Granada Press, 2007.

Bakar, Abu dan Chaider S. Bamualim. Filantropi Islam dan Keadilan Sosial. Jakarta: CSRC UIN Jakarta, 2006.

Departemen Agama RI. Pedoman Pengelolaan dan Pengembangan Wakaf. Jakarta: Direktorat Pemberdayaan Wakaf dan Direkterot Jenderal Bimbingan Masyarakat Islam Depag RI, 2006.

Efranie, Sairi. Wakaf Sebagai Instrumen Investasi, dalam Jusmaliani (ed). Kajian Teori Ekonomi Dalam Islam: Investasi Yang Islami. Jakarta: LIPI Press, 2007.

Huda, Nurul dan Mohamad Heykal. Lembaga Keuangan Islam: Tinjauan Teoritis Dan Praktis. Jakarta: Kencana Prenada Media Group, 2010.

Moelong, Lexy J. Metode Penelitian Kulitatif. Bandung :Remaja Rosdakarya, 1991.

Nasution, Mustafa Edwin dan Uswatun Hasanah, ed. Wakaf Tunai Inovasi Finansial Islam: Peluang dan Tantangan dalam Mewujudkan Kesejahteraan Umat. Depok: PSTTI-UI, 2006.

Ramulyo, Mohd. Idris. Hukum Perkawinan, Hukum Kewarisan, Hukum Acara Peradilan Agama dan Zakat. Jakarta: Sinar Grafika, 1995.

Sari, Elsi Kartika. Pengantar Zakat dan Wakaf. Jakarta: Grasindo, 2006.

Sugiyono, Metode Penelitian Kombinasi. Bandung: Alfabeta, 2008.

Syamsudin, M. Operasionalisasi Penelitian Hukum. Jakarta: PT. Raja Grafindo Persada, 2007.

Wadjdy, Farid dan Mursydi. Wakaf dan Kesejahteraan Umat: Filantropi Islam yang Hampir Dilupakan. Yogyakarta: Pustaka Pelajar, 2007. 
Undang-undang No. 41 Tahun 2004 Tentang Wakaf.

Peraturan Pemerintah No. 42 Tahun 2006 tentang Pelakasanaan UndangUndang No. 41 Tahun 2004 tentang Wakaf.

Peraturan Badan Wakaf Indonesia No. 1 Tahun 2009 tentang Pedoman Pengelolaan dan Pengembangan Harta Benda Wakaf Bergerak Berupa Uang.

Peraturan Badan Wakaf Indonesia No. 4 Tahun 2010 tentang Pedoman Pengelolaan dan Pengembangan Harta Benda Wakaf.

Peraturan Otoritas Jasa Keuangan Nomo 30/POJK.04/2016 Tentang Dana Investasi Real Estat (DIRE) Syariah.

Peraturan Otoritas Jasa Keuangan Nomo 19/POJK.04/2016 Tentang Dana Investasi Real Estat (DIRE).

Fatwa Tentang Wakaf Uang, Majelis Ulama Indonesia, Ditetapkan Tanggal 11 Mei 2002.

Fatwa DSN-MUI Nomor: 80/DSNMUI/III/2011.

Almantiq, Mifathul Huda. "Model dan Mekanisme Pengeolaan Wakaf Uang di Indonesia". Al-Awqaf. Vol. 10, No. 1 (2017).

Aziz, Muhammad. "Peran Badan Wakaf Indonesia (BWI) Dalam Mengembangkan Prospek Wakaf Uang di Indonesia." Al-Awqaf, Vol. 8, No. 2 (2015).

Dian, Masyita, et al. "A Dynamic Model for Cash Waqf Management As One Of the Alternative Instrument for the Poverty Allevation In Indonesia." disampaikan pada Massachutes Institute Technology, Boston Amerika Serikat (Juli, 2005).

Prakasa, Yoga. "Islamic Real Estate Invesment Trust as an Investment Asset for Waqf Management in indonesia". Dipresentasikan pada Konferensi Internasional Ekonomi Islam Gajah Mada yang ke-1, Yogyakarta, 2016.
Lestari, Diana. "Peran Reksa Dana Syariah Dalam Pengelolaan Wakaf Uang". Skripsi. Jakarta: Universitas Indonesia, 2004.

Satrio, Dono. "Perbandingan Model Pengelolaan Wakaf Uang Di Bangladesh dan Indonesia". Skripsi. Jakarta: UIN Syarif Hidayatullah, 2015.

Wardhani, Latifah K. "Pengelolaan Wakaf Uang dalam Bentuk Reksa Dana Syariah. (Suatu Tinjauan Hukum Pengeloaan Wakaf Uang dalam Bentuk Reksa Dana Syariah di Badan Wakaf Indonesia)". Skripsi. Jakarta: Universitas Indonesia, 2011.

Hotradero, Poltak. Bahan Paparan Kepala Divisi Manajemen Informasi Dan Pengembangan Emiten Bursa Efek Indonesia, "DIRE/REITS: Gambaran Global dan Prospek, Indonesia", Bursa Efek Indonesia, 2016. 